\title{
Species mass rearing technology for effective entomophages of harmful thrips in biolaboratories and their significance
}

\author{
Istam Saidov ${ }^{1, *}$ \\ ${ }^{1}$ Tashkent State Agrarian University, 100140, Tashkent province, Uzbekistan
}

\begin{abstract}
Scientific investigations devoted to technologies of mass rearing in biological laboratories of natural occurring species of entomophage of pest thrips are stated in this article. The technology of phytoseiulus rearing (Phitoseiulus persimilis Ah.) in the laboratory has been developed. According to this technology, rearing of phytoseiulus is conducted on legumes. At the same time, plants were grown in separate rooms, depending on their phases of development. With the formation of 15-20 leaves, the plants were infected with a spider mite. The air temperature was kept at $25-27^{\circ} \mathrm{C}$, and the relative humidity was $65-70 \%$. In such conditions, after 7-8 days, the number of spider mites on plants decreased, and the number of predatory mites increased. The entomophages collected from plants placed on vegetables crops. Plants in the laboratory were planted at the same time, which contributes to the frequency of collection of the entomophage.
\end{abstract}

\section{Introduction}

The problem of protecting various crops from harmful organisms (pests, diseases and weeds) remains relevant. FAO estimates pest damage at $\$ 1.4$ trillion, or $5 \%$ of the expected crop [1]. In this regard, improving the crop protection system is one of the most important tasks of agriculture [2, 3].

The existence of environmental problems, including in agriculture, determines the introduction of modern technologies into practice [4, 7]. In this connection, in recent years there has been an increase in the number of works on biological plant protection, improvement of modern technologies in plant protection, especially in the use of natural enemies of plant pests $[5,6]$. In our country, resource-saving technologies have been developed for reproduction in biolaboratory conditions of natural enemies of many pests, including thrips, which is a malicious enemy of plants in cotton and vegetable crops $[8,9]$. Such insects, polyphage-entomophages are: Phytoseiulus persimilis; Chrysopa carnea; Coccinella septempunctata and others. Despite this, further improvement of the technology is required along the way of making them cheaper, as well as increasing the field efficiency of their practical application. The scientific investigations devoted to technologies of mass

\footnotetext{
*Corresponding author: r.i.saidov@yandex.com
} 
breeding in biological laboratories of natural entomophagous species of thrips pests are presented in this paper.

\section{Materials and Methods}

A technology has been developed for breeding phytoseiulus (Phitoseiulus persimilis $A h$.) in the laboratory. Using this technology, phyto-seyulus was cultivated on legumes. At the same time, plants were grown in separate rooms, depending on their developmental phases. With the formation of 15-20 leaves, the plants were infected with a spider mite. The air temperature was kept $+25-27^{\circ} \mathrm{C}$, and the relative air humidity was $65-70 \%$. Under such conditions, after 7-8 days, the number of spider mites on the plants decreased, and the number of predatory mites increased. The entomophages collected from the plants were settled on vegetable crops. Plants in the laboratory were not planted at the same time, which contributes to the frequency of collection of the entomophage (Fig. 1).
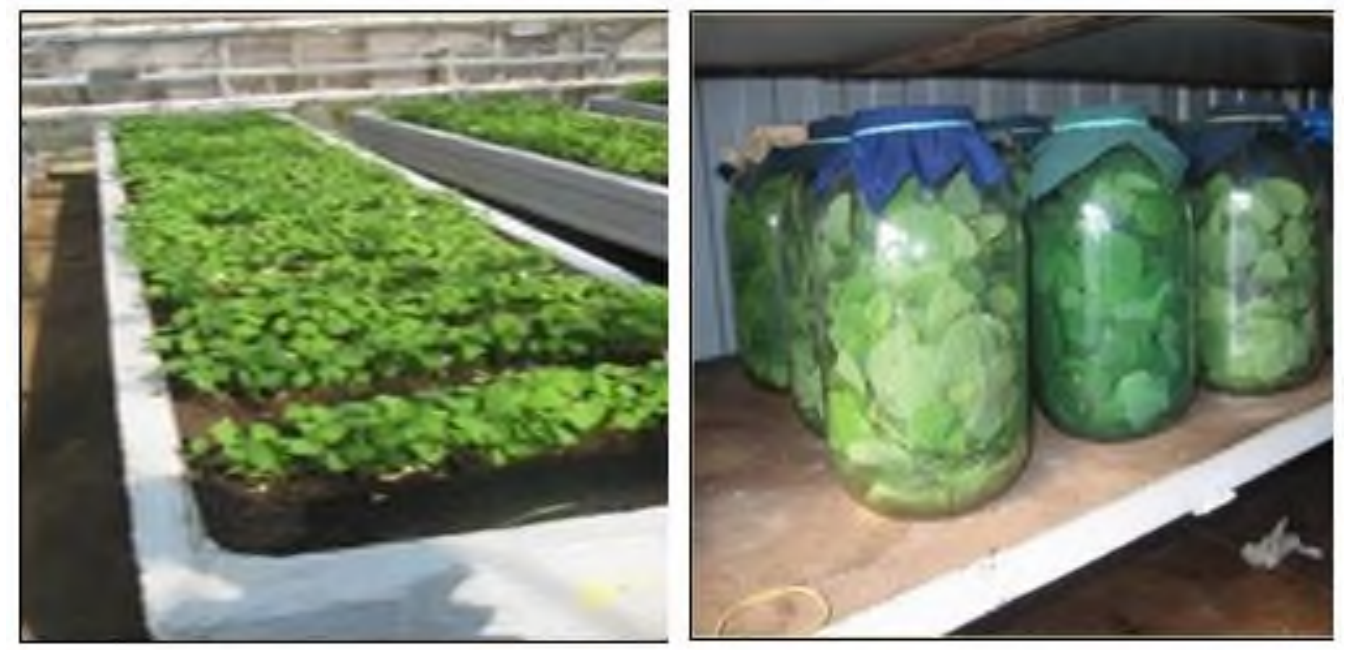

Fig. 1. A spider mite breeding in biological laboratories on legumes as food for breeding phytoseiulus

We have improved the technology of mass breeding of lacewings. For this purpose, a model (sample) of the device was developed, which ensures uninterrupted rearing of lacewing larvae on sitotroga eggs (Fig. 2). The use of this line avoids the need for threelitered glass jars and increases the productivity of the process. This production line has successfully passed production tests and is preparing the project for its wide industrial production and practical application.

\section{Results and discussion}

Along with the study of the biological characteristics of the development of tobacco thrips, it was necessary to study the importance of natural entomophages in reducing the number of pests. In 2016-2018, we conducted research in various districts of the Tashkent province on this issue. It was found that during the growing season on cotton there are 18 species of predatory entomophages belonging to five orders and nine families (Table 1). 

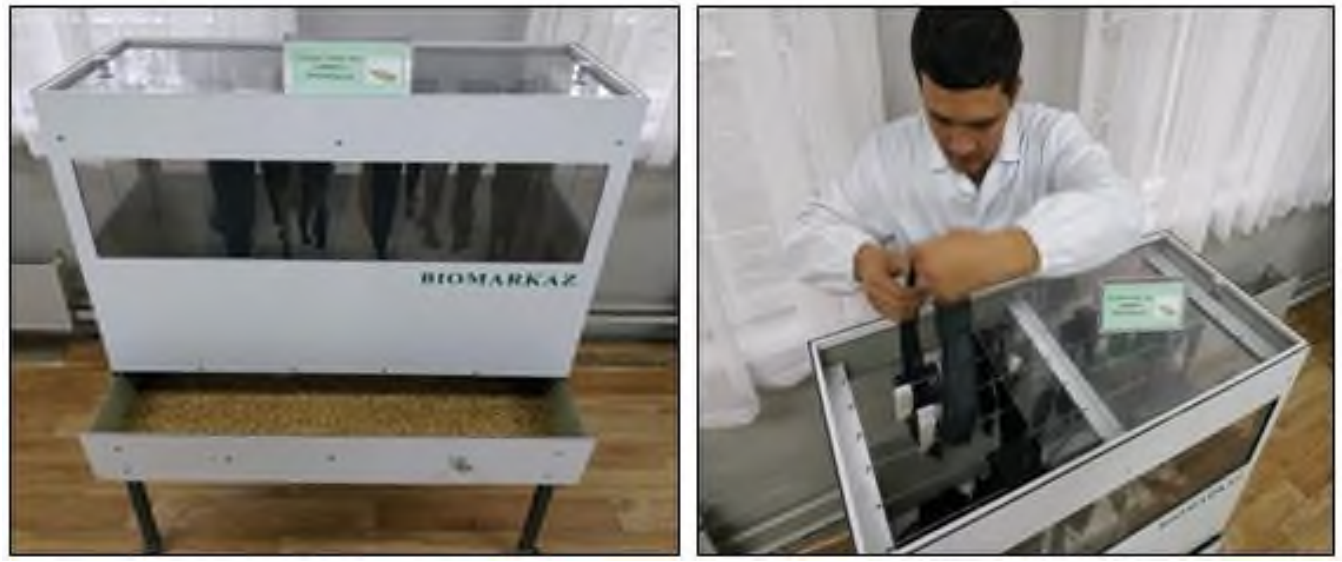

Fig.2. Process of breeding lacewings on a special predator reproduction line

Table 1. Entomophages found in cotton agrobiocenoses Farms in various districts of the Tashkent province, 2015-2018

\begin{tabular}{|c|c|c|}
\hline $\begin{array}{l}\text { Orders, } \\
\text { families }\end{array}$ & Types of entomophages & $\begin{array}{c}\text { Occurrence } \\
\text { of species }\end{array}$ \\
\hline Order & Hemiptera & \\
\hline \multirow[t]{2}{*}{ Family } & Nabidae & ++ \\
\hline & Nabis sp. & \\
\hline \multirow[t]{3}{*}{ Family } & Anthocoridae & \\
\hline & Orius niger & ++ \\
\hline & Qabbidipennis Reut & + \\
\hline \multirow[t]{5}{*}{ Family } & Miridae & \\
\hline & Makrolophus nubilis & +++ \\
\hline & Deraecoris punctulatus Schiff. & ++ \\
\hline & Campylomma verbasci m.d. & + \\
\hline & C.diversicornis Reat & \\
\hline Order & Thysonoptera & \\
\hline \multirow[t]{2}{*}{ Family } & Aeolothripidae & \\
\hline & Aeolothrips intermedius Baqn. & \\
\hline \multirow[t]{2}{*}{ Family } & Thripidae & \\
\hline & Scolothrips acariphagus Jakh & ++ \\
\hline Order & Coleoptera & \\
\hline \multirow[t]{5}{*}{ Family } & Coccinellidae & \\
\hline & Stethorus punctillum Wae & + \\
\hline & Adonia variegate $L$. & + \\
\hline & Coccinella undecimpunctata & ++ \\
\hline & C.septempunctata L. & +++ \\
\hline Order & Neoroptera & \\
\hline \multirow[t]{3}{*}{ Family } & Chrysopidae & \\
\hline & Chrysopa carnea Steph. & +++ \\
\hline & Ch.dubitans Ncl & + \\
\hline Order & Diptera & \\
\hline \multirow[t]{3}{*}{ Family } & Syrphidae & \\
\hline & Paragus tibialis Fall & \\
\hline & Jchiodon scutellaris $F$. & \\
\hline \multirow[t]{2}{*}{ Family } & Cecidomiidae & \\
\hline & Aphidoletes aphidimyza Rond & ++ \\
\hline
\end{tabular}

Note: + - rare appearance, ++- often appearance, +++ - common appearance 
We carried out a field experiment to study the voraciousness (efficiency) of coccinellid, a two-spotted ladybug, as a possible object for laboratory breeding, with practical application in the future.

For this, in special laboratory conditions, a population of ladybugs was grown on aphids that settled on legumes in pots. The insect beetles were then released in certain ratios on thrips-infested onion plants in a field belonging to a farm. Predatory beetles were released to certain areas in ratios from 1: 5 to 1:20 thrips units.

The scheme of the experiment and the results obtained are shown in Table 2, from which it can be seen that, in contrast to the control plot, in all the rest there is a decrease in the density of the pest. This is especially striking in the variants with predator-prey ratios of 1: 5 to $1: 15$, although in the variant with a ratio of $1: 20$ the density of the pest decreased by 2 or more times.

For the first time in the republic, acariphage mites were introduced: Phitoseiulus persimilis and Amblyseius mckenziei, a technology for breeding it in biological laboratories was created. The optimum temperature for phytoseiulus is $+25-27^{\circ} \mathrm{C}$, and the relative humidity is $65-70 \%$. With a stable supply of air temperature and humidity, premagonal development ends in 7-8 days. For amblyseiulus, the optimum temperature is $+25-28^{\circ} \mathrm{C}$, and the relative humidity of the air is $80-90 \%$, the preimagional development of which ends in 10-12 days.

16 species of predatory entomophagous insects have been registered, belonging to five orders and nine families feeding on tobacco thrips. It has been established that the dominant species are: Orius niger, Chrysopa carnea, C. septempunctata and Macrolophys nubiles, medium species are Deraecoris punctulatus, Campylomma verbasci, Scolothrips acariphagus, and rare species are C.diversicornis., Aeolgateorus. Puntillonia.

When using larvae of lacewings against tobacco thrips in ratios of 1:5 and 1:10 in agrobiocenoses of cotton and vegetable crops in the Tashkent region, the biological efficiency was $94.3-87.3 \%$, and when using the bug macrolophus nubilis, also in ratios $1: 5$ and $1: 10-83.4-81.1 \%$.

Table 2. Gluttony of the two-point ladybug in relation to tobacco thrips on onions Farm "Neptun Invest Agro", Zangiata district, Tashkent province, 2016-2018

\begin{tabular}{|c|c|c|c|c|c|c|c|c|c|c|c|}
\hline \multirow[t]{2}{*}{ \# } & \multirow[t]{2}{*}{ 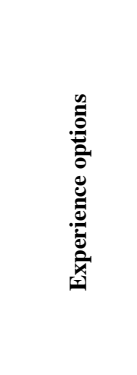 } & \multirow[t]{2}{*}{ 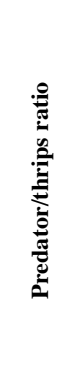 } & \multirow{2}{*}{ 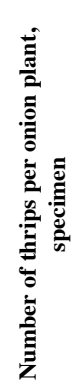 } & \multicolumn{4}{|c|}{ 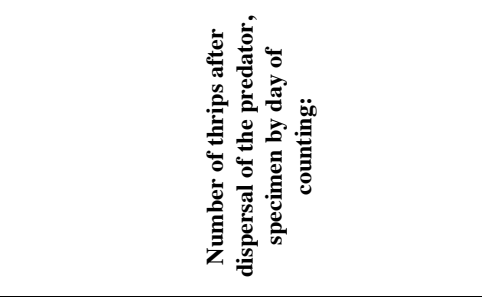 } & \multicolumn{4}{|c|}{ 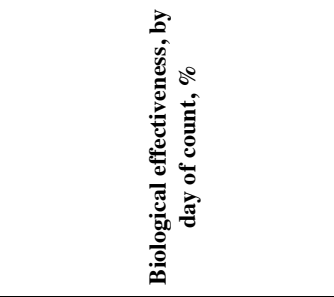 } \\
\hline & & & & 3 & 7 & 10 & 20 & 3 & 7 & 10 & 20 \\
\hline 1 & \multirow{4}{*}{$\begin{array}{l}\text { Experience: } \\
\text { predator } \\
\text { release }\end{array}$} & $1: 5$ & 20 & $1.7 \pm 0.2$ & 0 & 0 & $6.9 \pm 1.4$ & 93.9 & 100 & 100 & 77.5 \\
\hline 2 & & $1: 10$ & 20 & $10.7 \pm 1.9$ & $7.3 \pm 1.2$ & $2.7 \pm 0.3$ & $12.7 \pm 2.6$ & 62.0 & 76.6 & 92.3 & 58.6 \\
\hline 3 & & $1: 15$ & 30 & $13.3 \pm 3.1$ & $7.2 \pm 0.7$ & $9.6 \pm 2.3$ & $10.5 \pm 1.6$ & 68.5 & 84.6 & 81.8 & 77.1 \\
\hline 4 & & $1: 20$ & 20 & $13.7 \pm 2.2$ & $9.7 \pm 1.5$ & $16.2 \pm 4.2$ & $13.7 \pm 1.5$ & 52.2 & 69.0 & 52.9 & 55.3 \\
\hline 5 & $\begin{array}{l}\text { Control (no } \\
\text { predator) }\end{array}$ & - & 20 & $28.2 \pm 4.7$ & $31.3 \pm 6.3$ & $35.3 \pm 4.4$ & $30.7 \pm 1.7$ & - & - & - & - \\
\hline
\end{tabular}




\section{Conclusion}

A technology has been developed and a model has been created for a new line for laboratory breeding of lacewings. This line is much more efficient than the existing technology and provides a much larger number of lacewing eggs per unit area. This technology is resource-saving and saves working time and money, as well as electricity.

\section{References}

1. V.V. Yakhtonov, Thrips table, 1, 165 (1980)

2. V.V. Yakhtonov, Journal of Plant Protection, 12, 20-34 (1998)

3. G.D. Batler, G.I. May, J. Econ. Ent., 64(6), 1459-1461 (2001)

4. D.L. Kerns, M.J. Gaybor, South West. Entomol., 17, 259-264 (2012)

5. S.M. Vidyasekhar, G.P.V. Reddy, Pesticides, 23(8), 45-48 (2018)

6. M.V. Vecaria, G.M. Patel, Indian Journal of Entomology, 62(2), 150-158 (2019)

7. O.E. Heie, European Journal of Entomology, 91, 127-133 (1994)

8. S.N. Genjemuratovna, E.E. Gaybullaevich, K.J. Ubbiniyazovich, S.R. Sarsenbaevna, An Interdisciplinary Research Journal, 10(10), 599-604 (2020)

9. R. Kulmatov, A. Taylakov, S. Khasanov, Environmental Science and Pollution Research, 1-11 (2021) 